\title{
Synthesis of Platinum(II) Complexes of 4-Substituted o-Phenylenediamine Derivatives and Determination of Their Antitumor Activity
}

\author{
Yoshinori Kidani, Yoichi Asano, and Masahide Noji \\ Faculty of Pharmaceutical Sciences, Nagoya City University ${ }^{1)}$
}

(Received February 2, 1979)

\begin{abstract}
$\mathrm{Pt}(\mathrm{II})$ complexes of 4-substituted o-phenylenediamine (opda- $\mathrm{R} ; \mathrm{R}=\mathrm{CH}_{3}, \mathrm{OCH}_{3}, \mathrm{H}$, $\mathrm{Cl}, \mathrm{COOH}, \mathrm{NO}_{2}$, and $\left.\mathrm{SO}_{3} \mathrm{H}\right), \mathrm{PtX}_{2}$ (opda-R), were synthesized and tested for antitumor activity against P-388 leukemia. The infrared spectra of those complexes were analyzed to assign the Pt-N stretching vibrations on the basis of the halogeno trans effect and Hammett's $\sigma$ values. The assigned Pt-N strectching vibrations were related to the antitumor activities of the opda- $\mathrm{R} P t(\mathrm{II})$ complexes.
\end{abstract}

Keywords-_-antitumor activity; Pt(II) complexes; 4-substituted o-phenylenediamine; P-388 leukemia; assignments of Pt-N stretching.

Since the discovery of the antitumor activity of cis-dichlorodiammineplatinum(II) by Rosenberg et al. ${ }^{2)}$ various $\mathrm{Pt}$ complexes have been synthesized and tested for similar activity. Among them, o-phenylenediamine (opda-H) $\mathrm{Pt}(\mathrm{II})$ complex was reported to show antitumor activity. ${ }^{3,4)}$ We synthesized various $\mathrm{Pt}(\mathrm{II})$ complexes of opda- $\mathrm{R}$, in which the 4-position is occupied by various substituting groups, $\mathrm{CH}_{3}, \mathrm{OCH}_{3}, \mathrm{Cl}, \mathrm{COOH}, \mathrm{NO}_{2}$, and $\mathrm{SO}_{3} \mathrm{H}$, and examined the effects of these groups on the infrared spectra, and on the physiological activity.

\section{Experimental}

o-Phenylenediamine (Katayama Chemical Co., Ltd.), 4-methyl-, 4-chloro-, and 4-nitro-opda, and 3,4diaminobenzoic acid (Tokyo Kasei Chemical Co. Ltd.) were converted to their hydrochlorides. 4-Methoxyopda $2 \mathrm{HCl}$ was prepared by the reduction of 4-methoxy-2-nitroaniline, and 3,4-diaminobenzenesulfonic acid was prepared by the reduction of 2 -nitroaniline-4-sulfonic acid. $p$-Aniline derivatives were purified before use by distillation or recrystallization.

Synthesis of Complexes- $-\mathrm{PtCl}_{2}$ (opda-R) complexes were prepared according to the method of Connors et $a l .{ }^{3}$ ) by the reaction of potassium tetrachloroplatinate with hydrochlorides of opda- $\mathrm{R}$ in a $1: 1$ ratio in $1 \mathrm{~N} \mathrm{HCl} \mathrm{solution} \mathrm{for} \mathrm{one} \mathrm{day} \mathrm{at} 50^{\circ}$. The precipitates produced were collected and washed with water, acetone and ether, successively, then dried in vacuo. In the case of $\mathrm{R}=\mathrm{SO}_{3} \mathrm{H}$, the reaction solution was concentrated, and the precipitates were collected. $\mathrm{PtBr}_{2}$ (opda-R) and $\mathrm{PtI}_{2}$ (opda-R) were prepared in the same way as the dichloro complexes, in the presence of excess $\mathrm{KBr}$ and $\mathrm{KI}$. $\mathrm{PdCl}_{2}$ (opda-R) complexes were also prepared. by the method used for Pt complexes, by reacting potassium tetrachloropalladate with opda-R. cis-PtCl ${ }_{2}-$ $(p \text {-R-an })_{2}$ complexes, where $p$-R-an represents a $p$-substituted aniline derivative, were prepared by reacting potassium tetrachloroplatinate in water with $2 \mathrm{~mol}$ of $\mathrm{p}$ - R-an in aqueous acetone solution for one day, based on the method used for synthesizing cis-dichloro(dipyridine)platimun(II). ${ }^{5}$ ) Elemental analyses of all the complexes obtained were satisfactory, and are shown in part in Table $\mathrm{I}$.

Evaluation of Antitumor Activity-One million P-388 leukemia cells were transplanted intraperitoneally into $\mathrm{CDF}_{1}$ mice on day 0 . Treatment was given intraperitoneally twice (on days 1 and 5 ). The mean survival times of the treated $(T)$ and control $(C)$ groups (6 mice/group) were calculated, and the antitumor activity was expressed $T / C \%$. Values of $T / C \%$ exceeding 120 were taken as indicating effectiveness.

Apparatus_- Infrared spectra were measured with Jasco IRA-2 and ID-710G infrared spectrophotometers, by means of the $\mathrm{KBr}$ disc and aujol mull methods.

1) Location: 3-1 Tanabe-dori, Mizuho-ku, Nagoya 467, Japan.

2) B. Rosenberg, L. VanCamp, J.E. Trosko, and V.H. Mansour, Natuve (Iondon), 222, 385 (1969).

3) T.A. Connors, M. Jones, W.C. Ross, P.D. Braddock, A.R. Khokhar, and M.L. Tobe, Chem.-Biol. Interaction, 1972, 414.

4) L.M. Hall, R.J. Speer, H.J. Ridgway, and J.M. Hill, J. Clin. Hemat. and Oncol., 7, 877 (1977).

5) S.M. Jörgensen, J. Pract. Chem., 33, 489 (1886). 
TABlE I. Elemental Analysis of $\mathrm{PtCl}_{2}$ (opda-R) Complexes and Their Yields

\begin{tabular}{|c|c|c|c|c|c|c|c|}
\hline \multirow{3}{*}{ Pt(II) Complex } & \multirow{3}{*}{ Yield (\%) } & \multicolumn{5}{|c|}{ Analysis (\%) } & \\
\hline & & \multicolumn{3}{|c|}{ Calcd. } & \multicolumn{3}{|c|}{ Found. } \\
\hline & & $\mathrm{C}$ & $\mathrm{H}$ & $\mathrm{N}$ & $\mathrm{C}$ & $\mathrm{H}$ & $N$ \\
\hline $\mathrm{PtCl}_{2}$ (opda-CH $\mathrm{CH}_{3}$ ) & 70.3 & 2.60 & 21.66 & 7.22 & 2.73 & 21.73 & 7.37 \\
\hline $\mathrm{PtCl}_{2}\left(\right.$ opda-OCH $\left.{ }_{3}\right)$ & 84.6 & 2.49 & 20.80 & 6.94 & 2.54 & 21.14 & 6.65 \\
\hline $\mathrm{PtCl}_{2}$ (opda-H) & 94.7 & 2.15 & 19.26 & 7.49 & 2.04 & 19.05 & 7.81 \\
\hline $\mathrm{PtCl}_{2}$ (opda-Cl) & 93.7 & 1.73 & 17.63 & 6.86 & 1.63 & 17.87 & 6.78 \\
\hline $\mathrm{PtCl}_{2}$ (opda-COOH) & 91.0 & 1.93 & 20.11 & 6.70 & 2.06 & 20.06 & 6.53 \\
\hline $\mathrm{PtCl}_{2}\left(\right.$ opda- $\left.\mathrm{NO}_{2}\right)$ & 70.0 & 1.68 & 17.19 & 10.03 & 1.73 & 17.17 & 10.04 \\
\hline $\mathrm{PtCl}_{2}\left(\right.$ opda- $\left.\mathrm{SO}_{3} \mathrm{H}\right)$ & 60.0 & 1.77 & 15.86 & 6.17 & 2.33 & 15.71 & 6.31 \\
\hline
\end{tabular}

\section{Results and Discussion}

$\mathrm{PtCl}_{2}$ (opda-R) complexes were synthesized in high yields, as shown in Table I. They are hardly soluble in water, and the complexes and the ligands are both unstable in alkaline solutions. Therefore, the syntheses were performed in $1 \mathrm{~N} \mathrm{HCl}$ solution. This method is also useful in that it avoids $1: 2$ opda- $R$ complex formation.

\section{IR Spectral Analysis}

The main absorption bands due to the ligands of $\mathrm{PtCl}_{2}$ (opda- $\mathrm{R}$ ) are shown in Table II. The IR spectra of the Pt(II) complexes were analyzed mainly in the $700-400 \mathrm{~cm}^{-1}$ region, which contained the absorption bands due to Pt-ligand bonds. These bands indicate the nature of the coordination bond. We next attempted the assignment of $\mathrm{Pt}-\mathrm{N}$ stretching vibrations.

TABLE II. Infrared Spectral Data for $\mathrm{PtCl}_{2}$ (opda-R) Complexes

\begin{tabular}{|c|c|c|c|c|}
\hline $\begin{array}{l}\text { Substituent } \\
\text { group }(\mathrm{R})\end{array}$ & $\nu_{\mathrm{NH}_{2}}$ & $\delta_{\mathrm{NH}_{2}}$ & $\rho_{\mathrm{NH}_{2}}$ & Other bands $\left(\mathrm{cm}^{-1}\right)$ \\
\hline $\mathrm{CH}_{3}$ & 3210,3170 & 1541,1534 & 709 & \\
\hline $\mathrm{OCH}_{3}$ & 3205,3175 & $1556, \quad 1540$ & 737 & $\nu_{\mathrm{C}-0-\mathrm{C}} 1220,1103,1024$ \\
\hline $\mathrm{H}$ & 3210,3160 & 1546,1524 & 701 & \\
\hline $\mathrm{Cl}$ & 3200,3160 & 1535 & 703 & \\
\hline $\mathrm{COOH}$ & 3250,3190 & 1548 & 698 & $\nu_{\text {asy }}\left(\mathrm{CO}_{2} \mathrm{H}\right) \quad 1714, \quad \nu_{\mathrm{Syn}\left(\mathrm{CO}_{2} \mathrm{H}\right)} 1313$ \\
\hline $\mathrm{NO}_{2}$ & 3185,3140 & - & 758 & $\nu_{\mathrm{asy}\left(\mathrm{NO}_{2}\right)} \quad 1546, \nu_{\mathrm{syn}\left(\mathrm{NO}_{2}\right)} 1353,1321$ \\
\hline $\mathrm{SO}_{3} \mathrm{H}$ & 3195,3165 & 1549,1535 & 708 & $\nu_{\text {so }} 1135,1037$ \\
\hline
\end{tabular}

Figure 1 shows the IR spectra of opda- $\mathrm{CH}_{3}$ complexes together with that of the ligand. The band at $606 \mathrm{~cm}^{-1}$ of $\mathrm{PtCl}_{2}\left(\mathrm{opda}-\mathrm{CH}_{3}\right)$ was not observed in the ligand. When $\mathrm{Cl}^{-}$was replaced with $\mathrm{Br}^{-}$and $\mathrm{I}^{-}$, the corresponding peaks were shifted to 601 and $589 \mathrm{~cm}^{-1}$, respectively; these shifts toward lower wave number can be explained in terms of the trans effect of halogens. When the central metal ion of $\mathrm{PtCl}_{2}\left(\right.$ opda- $\left.\mathrm{CH}_{3}\right)$ was changed to $\mathrm{Pd}^{2+}$, a peak was found at $582 \mathrm{~cm}^{-1}$ in $\mathrm{PdCl}_{2}($ opda-CH $)$. These results are shown in Fig. 1.

In the case of $\mathrm{PtX}_{2}$ (opda-H) complexes, the peaks at 628,625 , and $613 \mathrm{~cm}^{-1}$ for $\mathrm{X}=\mathrm{Cl}$, $\mathrm{Br}$, and I, respectively, were the most sensitive to the trans effect of halogens. The peak at $628 \mathrm{~cm}^{-1}$ of $\mathrm{PtCl}_{2}$ (opda-H) was shifted to $613 \mathrm{~cm}^{-1}$ when $\mathrm{Pt}^{2+}$ was replaced with $\mathrm{Pd}^{2+}$.

Similar shifts to lower wave number on replacing $\mathrm{Pt}^{2+}$ with $\mathrm{Pd}^{2+}$ or on changing the halogen were reported for cis-dichloro platinum(II) complexes of diammine, ethylenediamine, and dipyridine. ${ }^{6)}$

6) J.R. Ferraro, "Low-Frequency Vibrations of Inorganic and Coordination Compounds," Plenum Press, New York, 1971, pp. 204-222. 


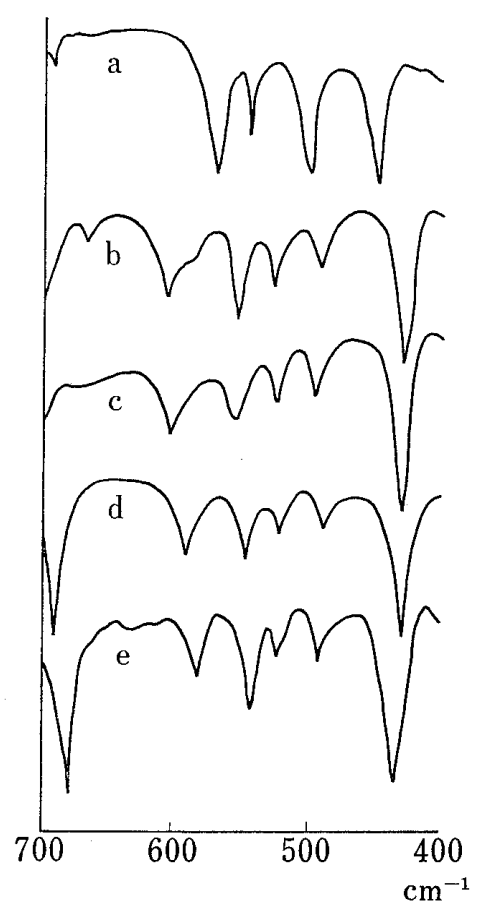

Fig. 1. Infrared Spectra of $\mathrm{Pt}(\mathrm{II})$ and $\mathrm{Pd}(\mathrm{II})$ Complexes of 4Methyl-o-phenylenediamine

a: opda- $\mathrm{CH}_{3} \cdot 2 \mathrm{HCl}$. b: $\mathrm{PtCl}_{2}$ (opda- $\mathrm{CH}_{3}$ ). c: $\mathrm{PtBr}_{2}$ (opda- $\mathrm{CH}_{3}$ ). d: $\mathrm{PtI}_{2}$ (opda- $\mathrm{CH}_{3}$ ) e: $\mathrm{PdCl}_{2}$ (opda- $-\mathrm{CH}_{3}$ ).

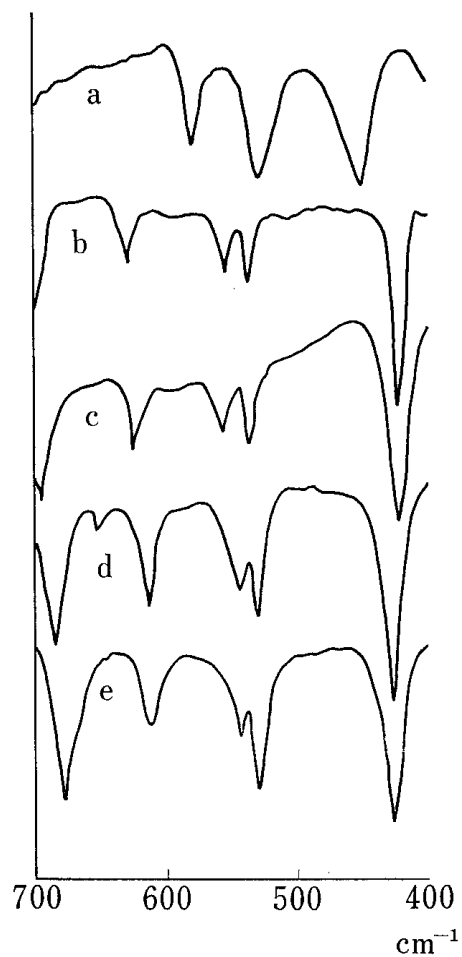

Fig. 2. Infrared Spectra of Pt(II) and Pd(II) Complexes of o-Phenylenediamine

a: opda-H. b: $\mathrm{PtCl}_{2}$ (opda-H).

c: $\mathrm{PtBr}_{2}$ (opda-H). d: $\mathrm{PtI}_{2}$ (opda-H).

e: $\mathrm{PdCl}_{2}$ (opda-H).

For the $\mathrm{Pt}(\mathrm{II})$ complexes of other opda derivatives, the $\mathrm{Pt}-\mathrm{N}$ stretching vibrations were assigned on the basis of similar considerations, and the results are tabulated in Table III. However, in the case of $\mathrm{PtCl}_{2}$ (opda- $\left.\mathrm{SO}_{3} \mathrm{H}\right)$, many bands appeared in the region of $700-400$ $\mathrm{cm}^{-1}$ and the assignment of the Pt-N stretching vibration was difficult. In order to confirm the validity of these assignments, $\mathrm{Pt}(\mathrm{II})$ and $\mathrm{Pd}(\mathrm{II})$ complexes of aniline derivatives with substituting groups at the para position, abbreviated as $\mathrm{p}$-R-an, were synthesized in order to compare their IR spectra with those of the opda-R Pt(II) complexes.

Figure 3 shows the IR spectra of $\mathrm{Pt}(\mathrm{II})$ and $\mathrm{Pd}(\mathrm{II})$ complexes of the aniline derivatives with $\mathrm{R}=\mathrm{CH}_{3}$ and $\mathrm{NO}_{2}$ together with those of the ligands. The peaks at 567 and $561 \mathrm{~cm}^{-1}$ of cis- $\mathrm{PtCl}_{2}\left(\mathrm{p}-\mathrm{CH}_{3}-\mathrm{an}\right)_{2}$ and cis- $\mathrm{PtCl}_{2}\left(\mathrm{p}-\mathrm{NO}_{2} \text {-an }\right)_{2}$, respectively, were not obserbed in the spectra of the ligands, and these peaks shifted to lower wave number, i. e. 557 and $550 \mathrm{~cm}^{-1}$, when $\mathrm{Pt}^{2+}$ was replaced with $\mathrm{Pd}^{2+}$. We therefore assigned the bands to the $\mathrm{Pt}-\mathrm{N}$ stretching

TABLE III. Assigned Pt-N and Pt-Cl Stretching Vibrations and Hammett's Sigma Values

\begin{tabular}{|c|c|c|c|c|c|c|c|}
\hline $\begin{array}{l}\text { Substituent } \\
\text { group (R) }\end{array}$ & $\begin{array}{l}\nu_{\mathrm{Pt}_{\mathrm{t}} \mathrm{N}^{a}} \\
\left(\mathrm{~cm}^{-1}\right)\end{array}$ & $\begin{array}{l}\nu \mathrm{Pt}-\mathrm{N}^{b)} \\
\left(\mathrm{cm}^{-1}\right)\end{array}$ & $\begin{array}{l}\nu_{\mathrm{Pt}-\mathrm{Cl}_{1}}^{b)} \\
\left(\mathrm{cm}^{-1}\right)\end{array}$ & $\sigma_{m}$ & $\sigma_{p}(-)$ & $\sigma_{m}+\sigma_{p}^{(-)}$ & $\mathrm{p} K_{\mathrm{a} 2}$ \\
\hline $\mathrm{CH}_{3}$ & 606 & 567 & $325, \quad 317$ & -0.07 & -0.13 & -0.20 & 4.68 \\
\hline $\mathrm{OCH}_{3}$ & 609 & 563 & 330,325 & +0.08 & -0.11 & -0.03 & 4.83 \\
\hline $\mathrm{H}$ & 628 & 573 & 330,318 & 0.00 & 0.00 & 0.00 & 4.47 \\
\hline $\mathrm{Cl}$ & 588 & 568 & 325,316 & +0.37 & +0.24 & +0.61 & 3.83 \\
\hline $\mathrm{COOH}$ & 580 & 566 & 333 & +0.36 & +0.73 & +1.09 & 3.49 \\
\hline $\mathrm{NO}_{2}$ & 578 & 561 & 330 & +0.71 & +1.27 & +1.98 & 2.61 \\
\hline
\end{tabular}

a) $\mathrm{Pt}-\mathrm{N}$ stretching vibrations of $\mathrm{PtCl}_{\mathbf{2}}$ (opda- $\mathrm{R}$ ).

b) $\mathrm{Pt}-\mathrm{N}$ and $\mathrm{Pt}-\mathrm{Cl}$ stretching vibrations of $\mathrm{PtCl}_{2}$ (p-R-an) $)_{2}$. 


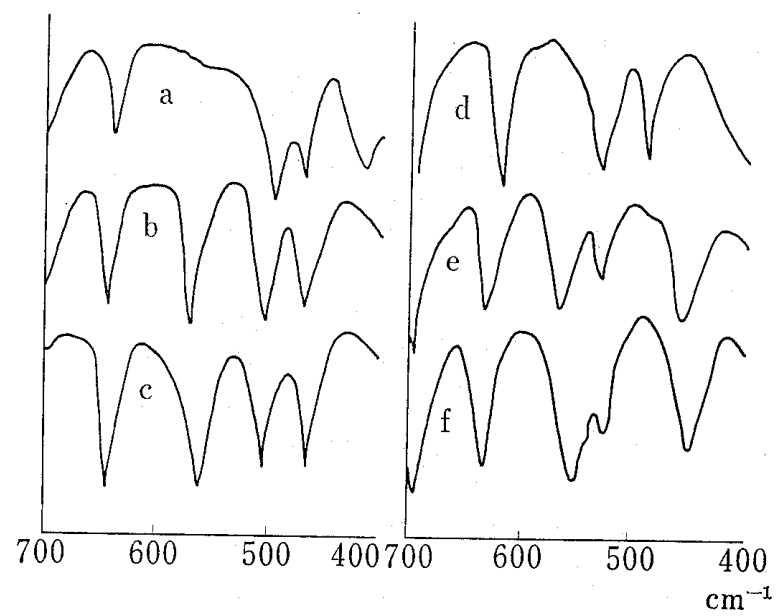

Fig. 3. Infrared Spectra of $\mathrm{Pt}(\mathrm{II})$ and $\mathrm{Pd}(\mathrm{II})$ Complexes of $p$-Substituted Aniline Derivatives

a: $p$-methylaniline. b: cis- $\mathrm{PtCl}_{2}\left(\mathrm{p}-\mathrm{CH}_{3}-\mathrm{an}\right)_{2}$. c: cis- $\mathrm{PdCl}_{2}\left(\mathrm{p}-\mathrm{CH}_{3} \text {-an }\right)_{2}$.

d: $p$-nitroaniline. e: cis- $\mathrm{PtCl}_{2}\left(\mathrm{p}-\mathrm{NO}_{2} \text {-an }\right)_{2}$. f: cis $-\mathrm{PdCl}_{2}\left(\mathrm{p}-\mathrm{NO}_{2}-\mathrm{an}\right)$ vibration. The cis configuration of $\mathrm{PtCl}_{2}-$ (p-R-an) ${ }_{2}$ was confirmed by the characteristic absorption bands due to symmetric and asymmetric stretching vibrations of $\mathrm{Pt}-\mathrm{Cl},{ }^{7)}$ as summarized in Table III. The $\mathrm{Pt}-\mathrm{N}$ stretching vibrations of $\mathrm{Pt}(\mathrm{II}) \mathrm{com}-$ plexes of other $\mathrm{p}$-R-an derivatives were assigned on the basis of similar considerations (Table III).

The $\mathrm{Pt}-\mathrm{N}$ bands of $c i s-\mathrm{PtCl}_{2}(\mathrm{p}-\mathrm{R}-\mathrm{an})_{2}$ were observed at $561-573 \mathrm{~cm}^{-1}$, while those of $\mathrm{PtCl}_{2}$ (opda-R) were observed in a higher wave number region, 578-628 $\mathrm{cm}^{-1}$. This indicates that the latter complexes are stabilized by the formation of a chelate ring.

\section{Relationship between the Hammett Values and Pt-N Stretching Vibrations}

Since the $\mathrm{p} K_{\mathrm{a}}$ values of the ligands affect the stability of the complexes, substitution effects on the assigned $\mathrm{Pt}-\mathrm{N}$ stretching were studied. Hammett's $\sigma$ values $\left(\sigma_{\mathrm{m}}, \sigma_{\mathrm{p}}\right.$, total values of $\sigma_{\mathrm{m}}+\sigma_{\mathrm{p}}$ ) for opda- $\left.\mathrm{R},{ }^{8}\right)$ the wave numbers of the $\mathrm{Pt}-\mathrm{N}$ stretching vibrations and the $\mathrm{p} K_{\mathrm{a} 2}$ values ${ }^{9}$ are shown in Table III. A plot of the $\mathrm{p} K_{\mathrm{a} 2}$ values against total values of $\sigma_{\mathrm{m}}+\sigma_{\mathrm{p}}$ was linear, but no linear relation was found between $\mathrm{p} K_{\mathrm{a} 1}$ and $\sigma$ values. $\mathrm{p} K_{\mathrm{a}}$ values are closely related to the stability constants of the complexes. If we postulate that larger stability constants correspond to stronger metal-ligand bonds, then a proportionality should exist between $\mathrm{Pt}-\mathrm{N}$ and total values of $\sigma_{\mathrm{m}}+\sigma_{\mathrm{p}}$. This was indeed the case, as shown in Fig. 5 .

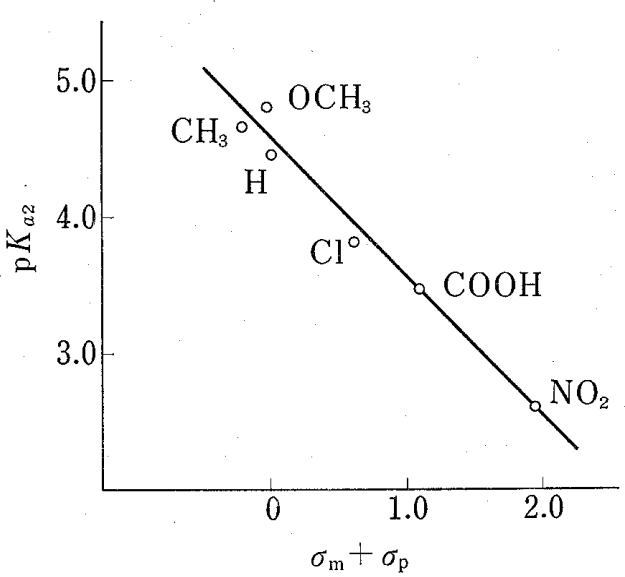

Fig. 4. Relationship between the Values of $\mathrm{p} K_{a_{2}}$ and the Sum of Hammett's Sigma Values for paraSubstituted $o$-Phenylenediamine Derivatives

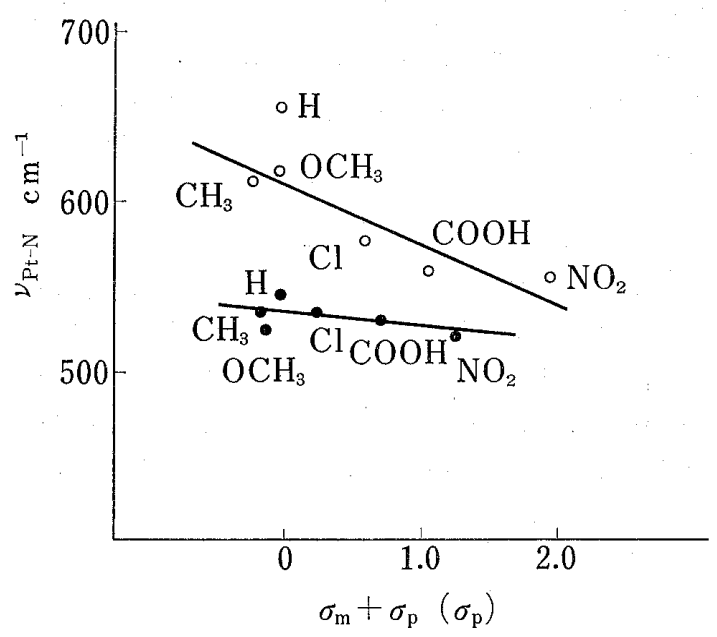

Fig. 5. Relationship between the Pt-N stretching Vibrations and Hammett's Sigma Values

$\mathrm{O}: \mathrm{PtCl}_{2}$ (opda-R). $:$ cis- $-\mathrm{PtCl}_{2}(\mathrm{p}-\mathrm{R}-\mathrm{an})_{2}$.

7) K. Nakamoto, "Infrared Spectra of Inorganic and Coordination Compounds," 2nd. Ed., Wiley-Interscience, New York, 1970, pp. 214-219.

8) J. March, "Advanced Organic Chemistry-Reaction, Mechanisms, and Structures," Tokyo Kagaku Dohjin, Tokyo, 1971, p. 297.

9) P. Vetesnik, J. Bielavsky, J. Kavalek, and M. Vecera, Collection Czech. Chem. Commun., 33, 2902 (1968). 
Thus we can predict the relative stability of the $\mathrm{Pt}(\mathrm{II})$ complexes for various substituting groups. The stability of opda- $\mathrm{Cl}$ is lower than those of opda- $\mathrm{H}$ and opda- $\mathrm{CH}_{3}$, and opda- $\mathrm{NO}_{2}$ is the least stable. This is reminiscent of the relationship between the stability constants of $\mathrm{Cu}(\mathrm{II})$ (opda-R) complexes and the total values of $\sigma_{\mathrm{m}}+\sigma_{\mathrm{p}}$, measured by Kina. ${ }^{10}$ )

In the case of $p$-substituted aniline derivatives, no marked differences in $\mathrm{Pt}-\mathrm{N}$ stretching vibrations were observed, but a similar relationship was observed between $\sigma_{\mathrm{p}}$ and $\mathrm{Pt}-\mathrm{N}$ stretching, shown in Fig. 5. These results also support the validity of the assignments of $\mathrm{Pt}-\mathrm{N}$ stretching vibrations of $\mathrm{PtCl}_{2}$ (opda-R).

\begin{tabular}{lcllll}
\multicolumn{5}{c}{ TABLE IV. } \\
\hline \\
\hline $\begin{array}{l}\text { Substituent } \\
\text { group (R) } \\
\text { Complexes against P-388 Leukemia }\end{array}$
\end{tabular}

Underlining indicates a positive effect $(T / C \leqq 120 \%)$.

\section{Antitumor Activity}

The results of antitumor screening tests of $\mathrm{PtCl}_{2}$ (opda-R) complexes against P-388 leukemia are shown in Table IV. The complex must maintain the $\mathrm{N}, \mathrm{N}$-coordination structures, which is required for activity, until it reaches the target DNA (the presumed site of action). Therefore, the higher the $\mathrm{Pt}-\mathrm{N}$ stretching vibration, the stronger the chelate ring of the complex, and the more likely it is that antitumor activity will appear. This may be why opda- $\mathrm{H}$ and opda- $\mathrm{CH}_{3}$ complexes showed higher activity. In the case of opda- $\mathrm{R}$, with $\mathrm{R}=\mathrm{COOH}$ and $\mathrm{SO}_{3} \mathrm{H}$, very low activity was seen. This may be explained by the fact that they both exist as ionic species, $\left[\mathrm{PtCl}_{2} \text { (opda-COO}\right]^{-}$and $\left[\mathrm{PtCl}_{2}\left(\text { opda- } \mathrm{SO}_{3}\right)\right]^{-}$, which would be unfavorable for penetration of the cell membranes.

Acknowledgements We are grateful to Dr. T. Tashiro for her work on the antitumor screening tests. This work was supported in part by Grants-in Aid for Cancer Research from the Ministry of Education, Science and Culture, Japan.

10) K. Kina and K. Toei, Bull. Chem. Soc. Japan, 44, 1289 (1971). 